\title{
Kappa-Casein Genotypic Frequencies in Holstein-Friesian Dairy Cattle in West Java Province
}

\author{
A. Anggraeni ${ }^{*}$, C. Sumantri ${ }^{\mathrm{b}}{ }^{\sharp}$, A. Farajallah ${ }^{\mathrm{c}}$, \& E. Andreas ${ }^{\mathrm{d} \#}$ \\ ${ }^{a}$ Indonesian Research Institute for Animal Production \\ Jln. Veteran III, Desa Banjarwaru, Ciawi - Bogor 16002 \\ ${ }^{b}$ Department of Animal Science and Technology, Faculty of Animal Science, Bogor Agricultural University \\ 'Department of Biology, Faculty of Science, Bogor Agricultural University \\ dPostgraduate of Faculty of Animal Science, Bogor Agricultural University \\ \#Jln. Agatis, Kampus IPB Darmaga, Bogor 16680 \\ (Received 19-03-2010; accepted 11-07-2010)
}

\begin{abstract}
Kappa casein ( $\mathrm{k}-\mathrm{cn})$ gene as one of the four casein genes commonly has two variant alleles. B allele is positively correlated with milk proteins, so potentially be used as MAS to improve milk protein content. This study aimed to identify genetic variation of the K-casein gene in HolsteinFriesian (HF) from several dairy regions in West Java. Blood samples were taken through jugular vein of lactating heifers and cows, from intensive managements under the Local Government Dairy Breeding Station - Cikole (BBPT Cikole-SP) (82 hds), Embryo Transfer Station (BET) (50 hds), and Eco Farm of Animal Science Faculty of Bogor Agricultural University (EcoFarm) ( $20 \mathrm{hds}$ ); as well as from semi-intensive managements of small dairy farmers under the supervision of the North Lembang Cooperative Unit (KPSBU Lembang) in two villages of Cilumber ( 98 hds) and Pasar Kemis (92 hds). Blood samples were also taken via cocsigalis vein of AI (active and non active) HF bulls at the two National AI Stations in Lembang ( $25 \mathrm{hds}$ ) and Singosari ( $32 \mathrm{hds})$. Identification of genetic variation was by applying PCR-RFLP method. Three genotypes were identified, namely AA, AB, and BB, resulting two alleles of $A$ and $B$. Results entirely showed that the frequencies of the BB $\mathrm{HF}$ female were very low, with the range of $0 \%-6 \%$ (vs AA genotype $=10 \%-54 \%$ and $\mathrm{AB}$ genotype $=46 \%-85 \%$ ), despite of the relatively high frequency of the B allele over the A allele ( $23 \%-48 \% \mathrm{vs} .52 \%-77 \%)$. The low frequency of the observed BB females might be due to the limited AI active BB bulls used for services by the two national AI stations $(0 \%-4 \%)$.
\end{abstract}

Key words: $\kappa-C n$ gene, BB genotype, milk protein, HF dairy cattle

\section{INTRODUCTION}

DNA polymorphic markers can be functioned as candidate genes in selecting quantitative traits. Markerassisted selection (MAS) combined with the traditional method of selection could be an effective way to be placed into the application of improving quantitative traits. This aid could increase the accuracy of selection and reduce interval generation, therefore accelerating selection responses (Drögemüller et al., 2001). Wu et al. (2005) stated that candidate genes of MAS might be defined as the genes that are able to response biologically to the desired traits (functional) or the genes that are closely linked to those of functional genes. The results of

\footnotetext{
* Correspondence author:

Indonesian Research Institute for Animal Production

Jln. Veteran III, Desa Banjarwaru, Ciawi - Bogor 16002

e-mail: ria.anneke@yahoo.co.id
}

identification can present variant genotypes of a number of loci (genes), making available information for genetic parameters in a population such as the frequencies of allel and genotype within breed of livestocks (Dogru \& Ozdemir, 2009).

Milk proteins are mainly divided into two fractions. The first is soluble fraction, named by whey protein, constituting the $\alpha$-lacto albumen and $\beta$-lacto globulin. The second is insoluble fraction, named by whole casein. Casein in dairy cattle is the main component of milk proteins constituting approximately $78 \%-82 \%$ milk proteins. Genetic polymorphism in milk protein genes can result in protein variants that differ in one or more amino acids, which are especially of interest when they are associated with protein composition, protein contents and milk production traits (Martin et al., 2002; Boettcher et al., 2004; Molina, 2006). Bovine casein is encoded by a $200 \mathrm{~kb}$ DNA fragment located at the chromosome 6/BTA 6q31 arranged in the order of $\alpha \mathrm{S} 1, \alpha \mathrm{S} 2, \beta$ and $\kappa$-casein 
fragment spans the $13 \mathrm{~kb}$ DNA sequence (Lien \& Rogne, 1993). The casein genes are tightly linked and inherited as a cluster so that taking a potential value and playing an important role in MAS for milk traits and protein percentages (Lien \& Rogne, 1993).

The kappa casein or $\kappa-C n$ of bovine constitutes approximately $12 \%$ of the whole milk casein. The overall length of the $\kappa-\mathrm{Cn}$ gene is close to $13 \mathrm{~kb}$, in the chromosome $6 \mathrm{q} 31$. The $\mathrm{k}-\mathrm{Cn}$ is considerably different from other caseins in structure and other properties (Azevedo et al., 2008). The genetic polymorphism of the $\kappa-C n$ gene in ruminant has been well documented providing cattle (Pinders et al., 1991; Rijnjkels et al., 1997), buffaloes (Pipalia et al., 2001; Otaviano et al., 2005; Patel et al., 2007; Riaz et al., 2008), goats (Angiolillo et al., 2002; Yahyaoui et al., 2003; Prinzenberg et al., 2005; Kiplagat et al., 2010), sheep (Moioli et al., 2007) and yak (Prinzenberg et al., 2008). Eleven variant alleles of the $\kappa-\mathrm{Cn}$ gene have been identified in cattle, namely A, B, C, D, E, F, G, H, Al, and J (Soria et al., 2003). However, only two alleles, namely $\mathrm{A}$ and $\mathrm{B}$ alleles, are the most commonly identified in Bos taurus dairy cattles (Beata et al., 2008). The A and $B$ variants differ in the amino acids 136 and 148. For the respective $\mathrm{A}$ and $\mathrm{B}$ alleles, threonine is replaced by isoleucine at position 136, while at position 148, aspartic acid is replaced by alanine respectively (Pinders et al., 1991).

The bovine protein variants have received considerable research interest in recent years because of possible associations between milk protein genotypes and economically important traits in dairy cattle. Many researches have indicated that certain milk protein variants may be associated with milk composition, milk proteins and cheese production (Robitaille et al., 2002; Comin et al., 2008; Heck et al., 2009). Therefore, milk protein genes could be useful as genetic markers for additional selection criteria in dairy cattle breeding. The casein fraction of milk proteins significantly influenced the composition and physico-chemical properties of the milk (Bovenhuis et al., 1992). Further, particular studies on the bovine $\kappa-\mathrm{Cn}$ variants resulted in its considerable association to lactation performance and had a major influence on milk composition, milk protein contents and its processing properties (Bovenhuis et al., 1992; VerdierMetz et al., 2001; Boettcher et al., 2004; Kübarsepp et al., 2005).

The Indonesian government policy in fulfilling the domestic fresh milk demand has taken place the main priority to develope Holstein-Friesian dairy breed, beside of a small number of the development of some Bos taurus dairy breeds and their crossbred. The maintenance of pure HF has been expected to produce high enough milk yield for individual lactating cow, so that the important consideration of imported HF bulls for producing frozen semen mainly based consideration on the high value of ETA for milk production. Protein is one of essential milk components as the source of nutritious food, therefore it was necessary to know how many cows with the BB genotype of the $\kappa-C n$ gene could contribute significantly to the protein content of the milk produced.
This research was aimed to know the frequencies of both genotype and allele of the $\kappa-\mathrm{CN}$ gene in HF heifers and cows under the two different research locations, both from government dairy breeding stations and a number of small dairy farmers in some central dairy area in West Java. This study was also to know how large the contribution of AI active HF bulls at the two national AI stations affected the frequency of the BB genotype cows in West Java Province.

\section{MATERIALS AND METHODS}

\section{Animal and Blood Samplings}

The study was performed on a total of 332 heifer and cow of Holstein-Friesian (HF). These animals were reared under two different managements, the first under an intensive management at the government breeding stasions and the second under a semi intensive management from a number of small dairy farmers under the supervision of the Milk Cooperative Unit of KPSBU Lembang. These two research locations were located in some dairy central areas in West Java. The first location was provided for the Local Government Dairy Cattle Breeding and Development Station named as BPPT-SP Cikole in Lembang District (82 hds), Embryo Transfer Station (BET) of Cipelang in Bogor District (50 hds), and Ecofarm of Faculty of Anim Science of Bogor Agricultural University (20 hds). The second location was provided for a number of small dairy farmers from the two villages of Cilumber ( 89 hds) and Pasar Kemis (92 hds) in the Cilumber Subdistrict, Lembang Regency, under the supervision of Milk Cooperative Unit in the North Lembang (KPSBU Lembang).

About $5 \mathrm{ml}$ blood was collected in K3-EDTA coated sterile vaccutainers and stored in a freezer until used for DNA extraction. Blood samples were collected via vena jugularis from all those HF heifers and cows. Blood samples were also collected via vena cocsigalis from HF males both actively used (bulls) and candidates (young sires) artificial insemination (AI) at the two AI Stations in Lembang ( $25 \mathrm{hds}$ ) and in Singosari (32 hds). The purpose of collecting blood from these HF males was to add more information over the contribution of the actively used AI bulls to the frequency distribution of genotypes and alleles of the $\mathrm{k}-\mathrm{Cn}$ gene in the HF females investigated.

\section{DNA Extraction}

Blood samples collected were stored at $4{ }^{\circ} \mathrm{C}$ and were used as DNA sources. DNA from approximately $5 \mathrm{ml}$ blood sample was extracted by phenolchloroform method as described by Sambrook et al. (1989) with minor modification. It was based on removal erythrocytes by successive washing in lysis buffer and subsequent lysis of leucocytes using SDS (sodium duadecyle sulphate) and proteinase $\mathrm{K}$ followed by extraction with phenol chloroform. Ten $\mathrm{ml}$ of blood taken on EDTA was mixed with $25 \mathrm{ml}$ cold sucrosetriton and the volume was completed to $50 \mathrm{ml}$ by autoclaved double distilled water. 
The solution was mixed well and the nuclear pellet was obtained by spinning and discarding the supernatant.

The nuclear pellet was suspended in lysis buffer (10 $\mathrm{mM}$ Tris base, $400 \mathrm{mM} \mathrm{NaCl}$ and $2 \mathrm{mM}$ sodium EDTA) pH 8.2, with $20 \%$ sodium dodecyl sulfate (SDS) and proteinase $\mathrm{K}(10 \mathrm{mg} / \mathrm{ml})$, and incubated overnight in a shaking water-bath at $37{ }^{\circ} \mathrm{C}$. Nucleic acids were extracted once with phenol, saturated with Tris-EDTA (TE) buffer (10 mM Tris, $10 \mathrm{mM} \mathrm{NaCl}$ and 1mM EDTA), followed by extraction with phenolchloroform-isoamyl alcohol (25:24:1) until there was no protein at the interface. This was followed by extraction with chloroformisoamyl alcohol (24:1). To each extraction, equal volume of the solvent was added, followed by thorough mixing and centrifugation for $10 \mathrm{~min}$. at $2000 \mathrm{rpm}$. The top layer was carefully transferred to another Falcon tube for the next extraction.

To the final aqueous phase, 0.1 volumes of $2.5 \mathrm{M}$ $\mathrm{Na}$ acetate and 2.5 volume of cold $95 \%$ ethanol were added. The tubes were agitated gently to mix the liquids and a fluffy white ball of DNA was formed. The DNA was picked up with a heat-sealed Pasteur pipette and washed briefly in $70 \%$ ethanol. The DNA was finally dissolved in an appropriate volume of $1 \mathrm{x}$ TE buffer. DNA concentrations were determined and diluted to the working concentration of $50 \mathrm{ng} / \mu \mathrm{l}$, which is suitable for polymerase chain reaction.

\section{Polymerase Chain Reaction (PCR)}

Analysis of PCR was done as followed: $2 \mu 150 \mathrm{ng}$ DNA sample, $0.25 \mu 150 \mathrm{ng}$ the kappa-casein (the к-Cn) gene primer, primer forward $(\mathrm{F})$ with the following sequence DNA 5' AAA TCC CTA CCA TCA ATA CC and $0.25 \mu \mathrm{l}$ primer reverse $(\mathrm{R})$ with the sequence DNA $5^{\prime}$ CTT CTT TGA TGT CTC CTT AG, $1.25 \mu 115 \mathrm{mM} \mathrm{MgCl}_{2}$ $1 \mu \mathrm{l} 2 \mathrm{mM}$ dNTPs dan $0.25 \mu \mathrm{l} 4$ Unit AmpliTaq gold DNA polymerase and added with $7.75 \mu \mathrm{l}$ milique water steril up to completing the total volume $12.75 \mu \mathrm{l}$. That tube was put into PCR machine under the programs as followed: $1^{\text {st }}$ stape, denaturation process at $94{ }^{\circ} \mathrm{C}$ for 10 minutes. Second stape, denaturation process at $94^{\circ} \mathrm{C}$ for 30 seconds, followed by annealing process (recombine) at $55{ }^{\circ} \mathrm{C}$ for 30 seconds then followed by extention process at $72^{\circ} \mathrm{C}$ for 1 minute. All the processes at $2^{\text {nd }}$ stapes were done up to 40 times. Third stape, adding extention at 72 ${ }^{\circ} \mathrm{C}$ for 5 minutes.

\section{Polymerase Chain Reaction-Restriction Fragment Length Polymorphism (PCR-RFLP)}

Analysis of PCR-RFLP was done in such a way that PCR product was cut by Pst I restriction enzyme. An amount of $4 \mu \mathrm{l}$ DNA from PCR product, $0.5 \mu \mathrm{l} 5$ unit of Pst I, $0.5 \mu \mathrm{l} 10 \mathrm{x}$ low buffer were taken into a $0.5 \mathrm{ml}$ eppendorf tube, added sterilized milique water up to the total volume $10 \mu \mathrm{l}$, and incubated at $37{ }^{\circ} \mathrm{C}$ for $60 \mathrm{~min}-$ utes. Elecrophoresis was carried out on a gel PAGE 1\% at 200 volt, for 60 minutes and coloured by silver nitrate for 20 minutes.

\section{Genotype Frequencies of the Kappa Casein Gene}

The genotype frequencies of the $\mathrm{K}-\mathrm{Cn}$ gene were calculated by dividing a number of the animal with a certain genotype over the total number of the three genotypes ( $\mathrm{AA}, \mathrm{AB}$, and $\mathrm{BB}$ ).

\section{Data Analysis}

Diversity of genotypes of each individu can be determined from the banding DNA found in genes. Each DNA fragment length compared to the length of the corresponding DNA (markers), then calculated the allelic frequency. The allele frequencies calculated using the formula Nei \& Kumar (2000):

$$
\mathrm{Xi}=(2 \mathrm{nii}+\Sigma \mathrm{nij}) /(2 \mathrm{n})
$$

Description:

$\mathrm{Xi}=$ frequency of allele $\mathrm{i}$-th

nii $=$ number of individuals of genotype ii

nij = number of individuals of genotype ij

$\mathrm{n}$ = number of samples

\section{RESULTS AND DISCUSSION}

\section{Amplification}

The currently existing advance technology of polymerase chain reaction (PCR) makes possible to amplify segments of the genome containing genotypic (allelic) variations be identified by the RFLP method. The PCR-RFLP technique has been used to study the frequency of the $\kappa-\mathrm{Cn}$ genotypes (alleles) in bovines as well as for dairy cattle (Alipanah et al., 2005; Azevedo et al., 2008). Identification of the variant genotypes of the $\kappa-C n$ gene in this study was also performed through the PCR-RFLP method. The DNA fragment amplified from the $\mathrm{AA}$ and $\mathrm{BB}$ genotypes were characterized by the presence of the only one fragment, corresponding to the fragment lengths of $152 \mathrm{bp}$ and $183 \mathrm{bp}$ respectively. The $\mathrm{AB}$ genotype, therefore, resulted in two restriction sites, constituting of $152 \mathrm{bp}$ and $183 \mathrm{bp}$. The patterns of the three possible $\kappa-C$ genotypes were shown in Figure 1.

A total number of 374 blood samples of HF heifers and cows collected under the intensive management farm at the government dairy breeding stations (Eco Farm of Faculty of Animal Science, Bogor Agricultural University, BET-Cipelang and BPPT-SP Cikole) and under the semi-intensive management at small dairy farmers (KPSBU Cilumber and Pasar Kemis) were successefully genotyped (Table 1). The results showed that those animals with the BB genotype were very low, at a range of $0 \%-6 \%$ with an average of $4 \%$. The observation under intensive management farm for HF heifers and cows at the Eco Farm (20 hd) and BET Cipelang (50 hd) showed that none of these animals had the BB genotype. Meanwhile in BPPT-SP Cikole showed that only a small number of the HF females in this location were with the BB genotype, at a frequency of 5\%. Furthermore, genotyping the $\mathrm{k}-\mathrm{Cn}$ gene under the semi intensive management from small dairy farms in Pasar Kemis and Cilumber villages of KPSBU Lembang also showed that the frequency of the $\mathrm{BB}$ animals was almost similar 


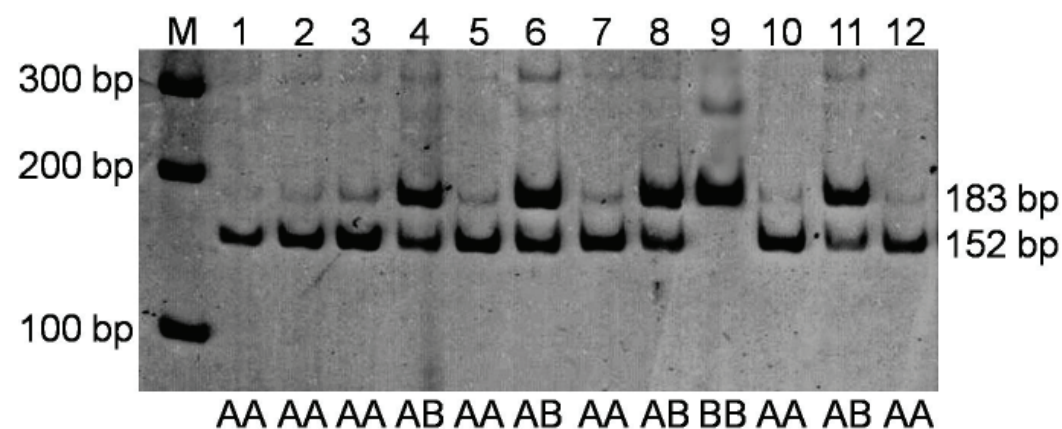

Figure 1. The RFLP patterns of the k-casein gene after digestion with Pst I on the $6 \%$ acrylamide gel. No. 1, 2, 3, 5, 7, 10, and 12. AA; No 4, 6, 8, and 11. AB; and No 9. BB; and M. Marker 100 pb ladder

to that in BPPT-SP Cikole of whose the BB frequencies were very low, $6 \%$ and $2 \%$ respectively.

The origin of the totally $50 \mathrm{HF}$ heifers and cows genotyped for their $\mathrm{k}-\mathrm{Cn}$ gene in BET Cipelang were imported from Australia and New Zealand. According to the main function of BET Cipelang, each animal would be functioned as donors and candidates for producing embryos. None of these animals was identified having the BB genotype implied that if the embryos they would produced be grown up to a mature age to re-produce embryos, then it would gave a large impact for the increasing number of offsprings with the AA and $\mathrm{AB}$ genotypes. The low $\mathrm{BB}$ frequency at the Eco Farm on the other side might be due to bulls countinously mated for females in this farm was only one HF bull that was identifted having the AA genotype of the $\kappa-\mathrm{Cn}$ gene. Under such this mating caused of resulting higher extence in producing the AA and AB offsprings. Table 1 also showed that the BB HF females at the small dairy farmers both in Cilumber (6\%) and Pasar Kemis (2\%) villages were very low.

A limited number of the BB HF females both in the BPPT-SP Cikole and small dairy farmers in KPSBULembang resulted in the low frequency of the BB genotype compared to those of the $\mathrm{AA}$ and $\mathrm{AB}$ genotypes.
The BB genotype frequencies in BPPT-SP $=5 \%$ and $\mathrm{KPSBU}=4 \%$ were lesser compared to either the $\mathrm{AB}$ genotype (BPPT-SP $=85 \%$; KPSBU $=63 \%$ ) or the genotype AA (BPPT-SP $=10 \%$; KPSBU $=31 \%$ ). This situation could be becoming an initial indication for a limited number of the BB genotype HF females in central dairy regions in West Java.

Both BPPT-SP Cikole and KPSBU-Lembang applied artificially insemination (AI) mating system to mate their HF females. Frozen semens were mostly bought from the two National AI Breeding Stations of BIB Lembang in West Java and BBIB Singosari in East Java, whereas in a small number of frozen semens were directly imported from some countries such as Canada and France. Therefore variant genotypes of the $\kappa-\mathrm{Cn}$ gene of the $\mathrm{HF}$ bulls in these two AI stations could give a large impact on the variant genotypes of the HF females they mated. Table 2 illustrated that for a total number of $32 \mathrm{HF}$ males reared in BBIB Singosari, 23 head of them were as the AI active bulls, however only one bull was having the $\mathrm{BB}$ genotype. Even, from the total 10 number of the AI active HF bulls in BIB Lembang, none of them was with the $\mathrm{BB}$ genotype $(0 \%)$. Based on such this situation, it can be known that the total BB frequency of the $\kappa-C n$ gene both at BIB Lembang $(0,26)$ and BIBB Singosari

Table 1. The frequencies of genotypes and alleles of the kappa casein gene in Holstein-Friesian heifers and cows by location

\begin{tabular}{|c|c|c|c|c|c|}
\hline \multirow{2}{*}{ Location and blood sample (Number) } & \multicolumn{3}{|c|}{ Genotype frequency (Sample) } & \multicolumn{2}{|c|}{ Allele frequency } \\
\hline & AA & $\mathrm{AB}$ & $\mathrm{BB}$ & A & B \\
\hline \multicolumn{6}{|l|}{ Intensive management } \\
\hline Eco Farm Fapet IPB (20) & $0.45(9)$ & $0.55(11)$ & $0.00(0)$ & 0.73 & 0.27 \\
\hline BET-Cipelang (50) & $0.54(27)$ & $0.46(23)$ & $0.00(0)$ & 0.77 & 0.23 \\
\hline BPPT-SP Cikole (82) & $0.10(8)$ & $0.85(70)$ & $0.05(4)$ & 0.52 & 0.48 \\
\hline Sub total (152) & $0.29(44)$ & $0.68(104)$ & $0.03(4)$ & 0.63 & 0.37 \\
\hline \multicolumn{6}{|l|}{ Semi intensive management } \\
\hline KPSBU - Cilumber (98) & $0.32(31)$ & $0.62(61)$ & $0.06(6)$ & 0.63 & 0.37 \\
\hline KPSBU - Pasar Kemis (92) & $0.34(31)$ & $0.64(59)$ & $0.02(2)$ & 0.66 & 0.34 \\
\hline Sub total (190) & $0.33(62)$ & $0.63(120)$ & $0.04(8)$ & 0.64 & 0.36 \\
\hline Total (342) & $0.31(106)$ & $0.65(224)$ & $0.04(12)$ & 0.64 & 0.36 \\
\hline
\end{tabular}


Table 2. Frequencies of genotypes and alleles of the kappa casein gene of the active AI bulls and AI candidates at National Artificial Inseminations of BIB Lembang and BBIB Singosari

\begin{tabular}{|c|c|c|c|c|c|}
\hline \multirow{2}{*}{ Location/Animal (head) } & \multicolumn{3}{|c|}{ Genotype frequency (\%) } & \multicolumn{2}{|c|}{ Allele frequency $(\%)$} \\
\hline & AA & $\mathrm{AB}$ & $\mathrm{BB}$ & A & B \\
\hline \multicolumn{6}{|l|}{ BIB Lembang } \\
\hline Active AI bulls (10) & $0.60(6)$ & $0.40(4)$ & $0.00(0)$ & 0.80 & 0.20 \\
\hline Progeny test candidates (15) & $0.56(8)$ & $0.33(5)$ & $0.13(2)$ & 0.70 & 0.30 \\
\hline Sub total (25) & $0.56(14)$ & $0.36(9)$ & $0.08(2)$ & 0.74 & 0.26 \\
\hline \multicolumn{6}{|l|}{ BBIB Singosari } \\
\hline Active AI bulls (23) & $0.17(4)$ & $0.78(18)$ & $0.04(1)$ & 0.57 & 0.43 \\
\hline Progeny test candidates (9) & $0.22(2)$ & $0.56(5)$ & $0.22(2)$ & 0.50 & 0.50 \\
\hline Sub total (32) & $0.19(6)$ & $0.72(23)$ & $0.09(3)$ & 0.55 & 0.45 \\
\hline Total & $0.35(20)$ & $0.56(32)$ & $0.09(5)$ & 0.63 & 0.37 \\
\hline
\end{tabular}

(0.45) was seemingly sufficient enough. However, almost all of them were possed by non active AI (young) males, so they would not given yet any contribution to increase the BB genotype females studied.

\section{Variant Alleles of the Kappa Casein Gene}

Due to the only three variant genotypes of AA, $\mathrm{AB}$ and $\mathrm{BB}$ of the $\kappa-\mathrm{Cn}$ gene were identifed in the $\mathrm{HF}$ males and females, so only two variant alleles, namely $\mathrm{A}$ and $\mathrm{B}$ were identified from these animals (Tabel 1 dan 2). Genetic variation among $A$ and $B$ alleles of the $\kappa-\mathrm{Cn}$ gene is well known due to the existing two-point mutation on the fourth exon (Eigel et al., 1984; Lien \& Roghe, 1993). Variants A and B differ in amino acid 136 and 148 at which at the position 136 the amino acid of Thr/ACC is changed by Ile (ATC) and at the position 148 that of Asp (GTA) is changed for Ala (GCT) (Pinders et al., 1991). The three of $\mathrm{AA}, \mathrm{AB}$, and $\mathrm{BB}$ genotypes identified in this result were accordance to other previous studies reporting the two variant $\mathrm{A}$ and $\mathrm{B}$ alleles of the $\kappa-\mathrm{Cn}$ gene as the two common alleles in Bos taurus dairy breeds (Beata et al., 2008).

The frequencies of the $\mathrm{A}$ and $\mathrm{B}$ alleles of the $\kappa-\mathrm{Cn}$ gene among locations was quietly wide (Table 1 and 2). For HF females under small dairy farmers at KPSBU Lembang, it was generally found that the A allele was higher compared to the B allele, both in Cilumber (0.63 vs 0.37) and Pasar Kemis (0.66 vs 0.34 ) villages. Contrastly, HF females at BPPT-SP Cikole had the frequencies of the $\mathrm{A}$ and $\mathrm{B}$ alleles almost similar (0.52 vs 0.48 ). However, all of observated HF females had a higher frequency for the A allele over the B $(0.64$ vs 0.36 ). The occurence of much higher the A allele than the $\mathrm{B}$ allele was also found for the active and non active AI males at the two AI stations of BIB Lembang (0.74 vs 0.26 ) and BBIB Singosari (0.63 vs 0.37 ). With regarding to the lower BB genotype females at Ecofarm, the reason for the lower frequency of the B allele over the A allele ( 0.27 vs 0.73 ) was that only one bull continously used for mating females and this bull was identified for the AA genotype.
In general, the A allele frequency of the $\kappa$-Cn gene of HF dairy cattles identified in this study was still lower compared to that in some countries such as USA, Europe and Japan of which having a higher A allele frequency at a range of 0.8-0.9 (Swaisgood, 1992). This was due to the main purpose to develope dairy cattle for high milk yield, at which the A allele is more related to higher milk yield, while the B allele closely associated with high protein yield. In related to this, it could partly be understood for the higher A allele frequency in HF females in this study as almost all active AI HF bulls used for mating were with the AA genotype (the A allele). This was can be associated with decision for the imported HF bull policy mainly based on high values of Estimated Transmitting Ability (ETA) of their milk yield. Van Eenennaam \& Medrano (1991) stated dairy breeds (Bos taurus) could change largely on the allele frequencies of the $\kappa-\mathrm{Cn}$ gene by the way of exploiting superioriry of lactation traits. It was reported that animals with high fat yield such as Jersey and Brown Swiss were generally with a high frequency of the A allele (0.67-0.86), in contrast, high milking dairy breeds such as Holstein, Guernsey and Milking Shorthorn commonly having a low frequency of the B allele (0.11-0.27). It was further explained that a consistent selection on lactation traits either for milk yield or milk composition could effectively change locus frequencies of the $\kappa-C n$ gene from time to time. Selection on lactation traits for around two decades (1964-1990) in Holstein was reported decreasing the $\mathrm{B}$ allele of the $\kappa-\mathrm{Cn}$ gene from 0.20 to 0.18 , on the contrary, selection on milk fat in Brown Swiss resulted in the increasing $B$ allele from 0.59 to 0.67 . A higher gene frequency of the A variant vs B (0.73 vs 0.27$)$, as already reported in Holstein-Friesian (Boettcher et al., 2004; Kübarsepp et al., 2005). An interesting latitude trend for the $\kappa-C n$ gene was observed in European cattle breeds with highest frequencies related to the $\kappa-\mathrm{Cn}$ variant $\mathrm{A}$ in North Western Europe (Jann et al., 2004).

\section{CONCLUSION}

Genotyping $\mathrm{K}$-casein gene in HF dairy cattle resulted in three variant genotypes, namely the $A A, A B$ 
and BB genotypes, so two variant alleles were identified, namely the A and B alleles. The BB genotype HF females in this study were identified at a very low frequency in the range of $0 \%-6 \%$. None of HF females genotyped in both BET Cipelang and Eco Farm had the BB genotype of the $\mathrm{K}$-casein gene. The occasion of the BB HF females both in the BPPT-SP Cikole and small dairy farmers in KPSBU-Lembang at a very low frequency (2\%-5\%) contrasted to the AA and $\mathrm{AB}$ genotypes $(10 \%-34 \%$ and $46 \%-85 \%$ respectively) was mainly due to the limited number of the active AI HF bulls with the BB genotype reared in the two national AI stations. All of this finding could be a possible indication for a small number of the BB genotype HF females in some central dairy region in West Java.

\section{REFERENCES}

Alipanah, M., L. Kalashnikova, \& G. Rodionov. 2005. KappaKasein genotypic frequencies in Russian breeds Black and Red Pied cattle. Iran. J. Biotechnol. 3:191-194.

Angiolillo, A., M. H. Yahyaoui, A. Sanchez, F. Pilla, \& J. M. Folch. 2002. Characterization of new genetic variant in the caprine k-casein gene. J. Dairy Sci. 85: 2679-2680.

Azevedo, A. L. S., C. S. Nascimento, R. S. Steinberg, M. R. S. Carvalho, M. G. C. D. Peixoto, R. L. Teodoro, R. S. Verneque, S. E. F. Guimarães, \& M. A. Machado. 2008. Genetic polymorphism of the kappa-casein gene in Brazilian cattle. Genet. Mol. Res.7: 623-630.

Beata, S., N. Wojciech, \& W. Ewa. 2008. Relations between kappa-casein polymorphism (CSN3) and milk performance traits in heifer cows. J. Cent. Eur. Agric. 9: 641-644.

Boettcher, P. J., A. Caroli, A. Stella, S. Chessa, E. Budelli, F. Canavesi, S. Ghiroldi, \& G. Pagnacco. 2004. Effects of casein haplotypes on milk production traits in Italian Holstein and Brown Swiss cattle. J. Dairy Sci. 87:4311-4317.

Bovenhuis, H., J. A. M. van Arendonk, \& S. Kerver. 1992. Associations between milk protein polymorphism and milk production traits. J. Dairy Sci.75:2549-2559.

Comin, A., M. Cassandro, S. Chessa, M. Ojala, R. Dal Zotto, M. De Marchi, P. Carnier, L. Gallo, G. Pagnacco, \& G. Bittante. 2008. Effects of composite $\beta$ - and $\kappa$-casein genotypes on milk coagulation, quality, and yield traits in Italian Holstein cows. J. Dairy Sci. 91:4022-4027.

Dogru, U. \& M. Ozdemir. 2009. Genotyping of kappa-casein locus by PCR-RFLP in Brown Swiss cattle breed. J Anim. and Vet. Advances. 8:779-781.

Drögemüller, C,. A. Bader, H. Kuiper, T. Leeb, J. L. Williams, \& O. Distl. 2001. Assignment of the bovine runt-related transcription factor 1 gene (RUNX1) to bovine chromosome $23 \mathrm{q} 21$ by fluorescence in situ hybridization and radiation hybrid mapping. Cytogenet. Cell Genet. 94:248-249.

Eigel, W. N., J. F. Butler, C. A. Ernstrom, H. M. Farrell, V. R. Harwalkar, R. Jennes, \& R. McL Whitney. 1984. Nomenclature of proteins of cow's milk. J.Dairy Sci. 67:1599-1631.

Heck, J. M. L., A. Schennink, H. J. F. van Valenberg, H. Bovenhuis, M. H. P. W. Visker, J. A. M. van Arendonk, \& A. C. M. van Hooijdonk. 2009. Effects of milk protein variatns on the protein composition of bovine milk. J. Dairy Sci. 92:1192-1202.

Jann, O., Ibeagha-Awemu, C. E-Özbeyaz, P. Zaragoza, J. L. Williams, P. Ajmone-Marsan, J. A. Lenstra, K. MoazamiGoudarzi, \& G. Erhardt. 2004. Geographic distribution of haplotype diversity at the bovine casein locus. Genet. Sel.
Evol. 36: 243-257.

Kiplagat, S. K., M. Agaba, I. S. Kosgey, M. Okeyo, D. Indetie, O. Hanotte, \& M. K. Limo. 2010. Genetic polymorphism of kappa-casein gene in indigenous Eastern Africa goat populations. Int. J. Genet. and Mol. Biol. 2: 001-005.

Kübarsepp, I., M. Henno, H. Viinalass, \& D. Sabre. 2005. Effect of $\kappa$-casein and $\beta$-lactoglobulin genotypes on the milk rennet coagulation properties. Agr. Res. 1: 55-64.

Lien, S. \& S. Rogne. 1993. Bovine casein haplotypes: number frequencies and applicability as genetic markers. Anim. Genet. 24: 373-376.

Martin, P., M. Szymanowska, L. Zwierzchowski, \& C. Leroux. 2002. The impact of genetic polymorphisms on the protein composition of ruminants milks. Reprod. Nutr. Dev. 42:433-459.

Moioli, B., D. M. Andrea, \& F. Pilla. 2007. Candidate genes affecting sheep and goat milk quality. Small Rumin. Res. 68: 179-192.

Molina, L. H., J. Kramm, C. Brito, B. Carrillo, M. Pinto, \& A. Ferrando. 2006. Protein composition of milk from Holstein-Friesian dairy cows and its relationship with the genetic variants $A$ and $B$ of $\kappa$-casein and $\beta$-lactoglobulin (Part I.). Int. J. Dairy Technol. 59:183-187.

Nei, M., \& S. Kumar. 2000. Molecular Evolution and Phylogenetics. Oxford University Press, New York.

Otaviano, A. R., H. Tonhati, J. A. D. Sena, \& M. F. C. Munoz. 2005. Kappa-casein gene study with molecular markers in female buffaloes (Bubalus bubalis). Genet. Mol. Bio. 28:237-241.

Patel, R. K., J. B. Chauhan, K. M. Singh, \& K. J. Soni. 2007. Genotyping and alleleic frequencies of $\kappa-\mathrm{CN}$ and $\beta$-LG in Indian river buffalo bulls. Buffalo Bull. 26: 63-66.

Pinders, J., B. N. Perryc, J. Skidmoraend, \& D. Sawa. 1991. Analysis of polymorphism in the bovine casein genes by use of the polymerase chain reaction. Anim. Genet. 22:11-20.

Pipalia, D. L., D. D. Ladani, B. P. Brahmkshtri, D. N. Rank, C. G. Joshi, P. H. Vataliya, \& J. V. Solanki. 2001. Kappa-casein genotyping of Indian buffalo breed using PCR-RFLP. Buffalo J. 2:195-202.

Prinzenberg, E. M., K. Gutscher, S. Chessa, A. Caroli, \& G. Erhardt. 2005. Caprine kappa-Casein (CSN3) polymorphism: New developments in molecular knowledge J. Dairy Sci. 88: 1490-1498.

Prinzenberg, E. M., H. Jianlin, \& G. Erhardt. 2008. Genetic variation in the K-Casein gene (CSN3) of Chinese yak (Bos grunniens) and phylogenetic analysis of CSN3 sequences in the Genus Bos. J. Dairy Sci. 91:1198-1203

Riaz, M. N., N. A. Malik, F. Nasreen, \& J. A. Qureshi. 2008. Moleculer marker assisted study of kappa-casein gene in NILI-RAVI (Buffalo) breed of Pakistan. Pakistan Vet. J. 28: 103-106.

Rijnkels, M., P. M. Kooiman, H. A. deBoer, \& F. R. Pieper. 1997. Organization of the bovine casein gene locus. Mammalian Genome. 8:148-152.

Robitaille, G., M. Britten, J. Morisset, \& D. Petitclerc. 2002. Quantitative analysis of B-lactoglobulin A \& B genetic variants in milk of cows B-Lactoglobulin $A B$ throughout lactation. J. Dairy Sci. 69: 651-654.

Sambrook, J., E. F. Fritsch, \& T. Maniatis. 1989. Molecular Cloning Laboratory Manual. $3^{\text {rd }}$ Ed. Cold Spring Harbour Lab. Press, New York.

Soria, L. A., G. M. Iglesias, M. J. Huguet, \& S. L. Mirande. 2003. A PCR-RFLP test to detect allelic variants of the bovine kappa-casein gene. Anim. Biotechnol. 14: 1-5.

Swaisgood, H. E. 1992. Chemistry of Caseins. In Advanced Dairy Chemistry-1 Proteins. P.F. Fox (Ed.). Elsevier Applied Science London and New York. pp: 63-110.

Van Eenennaam, A. J. \& J. F. Medrano. 1991. Milk protein 
polymorphisms in California dairy cattle. J. Dairy Sci. 74:1730-1740.

Verdier-Metz I., J. B. Coulon, \& P. Pradel. 2001. Relationship between milk fat and protein contents and cheese yield. Anim. Res. 50:365-371.
Wu, C. H., L. Yeh, H. Huang, L. Arminski, J. Castro-Alvear, Y. Chen, Z. Hu, P. Kourtesis, R. S. Ledley, B. E. Suzek, C. R. Vinayaka, J. Zhang, \& W. C. Barker. 2005. The Protein Information Resource. Nucleic Acids Res. 31: 345-347.

Yahyaoui, M. H, A. Angiolillo, F. Pilla, A. Sanchez, \& J. M. Folch. 2003. Characterization and genotyping of the caprine kappa casein variants. J. Dairy Sci. 86: 2715-2720. 